\title{
Chemical And Carbon Isotopic Gas \\ Compositions From The Wolfcamp In Permian Basin And Their Geological Significance
}

TONGwei Zhang, LuCY Tingwei Ko, Xun Sun, Di MENG AND SCOTT HAMLIN ${ }^{1}$

${ }^{1}$ Bureau of Economic Geology, Jackson

School of Geosciences, The University of

Texas at Austin, Austin, TX 78713, United

States

Wolfcamp mudrocks in the Permian Basin have, in the past few years, become one of the primary targets for mudrock oil production. Mud gas logging has been widely used for determining gas and oil shows during drilling. Can the technology be used for well completion? It is a challenging issue to determine the length of induced hydraulic fractures. Artificial tracers are injected and used for well completion, however, their concentrations can be dramatically diluted by in-situ reservoir fluids or by adsorption on minerals. New findings of obvious differences in gas chemical and carbon isotopic compositions between Wolfcamp A and B units provide some important hints as geochemical tracers for well completion in this study. Gas chemical and carbon isotopic compositions can be used to better constrain differences in organic matter type and thermal maturity among Wolfcamp units. We used cores from two closely spaced wells from northern Reagan County, Texas and cuttings from a Howard County well about 51 miles $(80 \mathrm{~km})$ away. For a comparison purpose, a cored well in Reeves County, Texas was used in this study as well. Wolfcamp A, B, C, and D units were correlated using gamma ray and resistivity wireline logs.

The chemical composition of the gas released from rock crushing was conducted and integrated with Rock-Eval pyrolysis to define the effect of lithoolgy variation on a short distance of oil vertical migration in this study. We observed differences in gas compositions among Wolfcamp A units associated with lithofacies variations. Much lower gas dryness $(\mathrm{C} 1 / \mathrm{C} 1-5)$ in the middle part of Wolfcamp A are associated with meter-scale cyclicity of siliceous mudstone and wackestone. Fine-grained thin carbonate beds in these meter-scale cycles serve as reservoirs and receive migrated oil from underlying TOC-rich siliceous mudstones. Variations in organic matter type rather than thermal maturity play an important role in the change of carbon isotopic compositions in Wolfcamp A and B units. Crushed rock gas data from cored wells in this study provide important reference data for the interpretation of gas logging and rock properties. 